\title{
The Origins of the ASEAN Community's Humanitarian Component
}

\author{
Kwei-Bo Huang \\ Department of Diplomacy \\ College of International Affairs \\ National Chengchi University (NCCU) \\ Taipei City 11605, Taiwan \\ kweibo@nccu.edu.tw
}

Published 23 April 2019

\begin{abstract}
The birth of the ASEAN Community in 2007 has strengthened a long ignored part of ASEAN, i.e., humanitarian assistance and development. The three major pillars of the ASEAN Community have either direct or indirect influence on the institutional expansion and capacity building of ASEAN's humanitarianism-related tasks. The direct influence is usually derived from the ASEAN Political and Security Community and the ASEAN Social and Cultural Community, while the indirect influence can rest on the advance of the ASEAN Economic Community. Meanwhile, leaders of ASEAN also work with extra-regional state and non-state actors to ensure the positive humanitarian development within the region of Southeast Asia. Yet, due to the principle of non-interference and the lack of resources, ASEAN's early effort - mainly in capacity building - has apparently been less effective after the brief study of three cases.
\end{abstract}

\section{Keywords}

ASEAN Community; ASEAN Political and Security Community (APSC); ASEAN Social and Cultural Community (ASCC); humanitarian; disaster assistance and relief.

This is an Open Access article, copyright owned by World Scientific Publishing Company (WSPC) and School of International Relations and Public Affairs of Shanghai International Studies University (SIRPA of SISU). The article is distributed under the Creative Commons Attribution 4.0 (CC BY-NC) Licence. Further distribution of this work is permitted, provided the original work is properly cited and for non-commercial purposes. 


\section{Introduction}

In 1967, the year when the Association of Southeast Asian Nations (ASEAN) was founded, Foreign Ministers of ASEAN established the ASEAN Permanent Committee on Socio-Cultural Activities to implement social and humanitarian projects including operations against natural disasters. In practice, nevertheless, ASEAN did not take such an issue seriously probably until the beginning of the new millennium. The Declaration of ASEAN Concord II (Bali Concord II), signed in October 2003 for the purpose of establishing the ASEAN Community, serves as an important milestone in the pursuit of a humanitarian context in ASEAN. Growing calls for humanitarian assistance and disaster relief have become too strong to ignore both because some major natural disasters hit Southeast Asia and caused a number of casualties and because lots of Southeast Asian people still feel growing pain over inequality and injustice derived largely from economic globalization, regional diversified developments, and politicosocial disparity.

After having studied the key ASEAN documents on the relevance of the ASEAN Community and emergent humanitarian concern, this paper examines ASEAN's performance in regional and international treaties and declarations with humanitarian components to further examine the growing interest of ASEAN in humanitarianism. At the end of this paper, ASEAN's efforts in institutional development and capacity building in humanitarianism are brought up to identify some immediate flaws that have not been corrected since the inception of the ASEAN Community.

To keep the analysis as simple and clear as possible, this paper simply touches upon two aspects of humanitarian concerns often discussed by ASEAN at the beginning of the ASEAN Community, i.e., humanitarian assistance and disaster relief, as well as rural development and poverty reduction. Institutional arrangements and policy recommendations of ASEAN having to do with regional or national security have to be neglected, although a more secure environment can certainly help promote the humanitarian condition in Southeast Asia. Besides, closing the development divide and accelerating economic integration are also of significance for the people in Southeast Asia, but this paper will not discuss them. 


\section{The ASEAN Community's Birth with a Growing Call for Humanitarianism}

In October 2003, 10 national leaders of ASEAN met in Bali, Indonesia, and announced their plan to establish the ASEAN Community in 2020. The Bali Concord II set up a comprehensive framework to achieve a cohesive and resilient ASEAN Community which consists of the ASEAN Security Community (ASC), the ASEAN Economic Community (AEC), and the ASEAN Socio-Cultural Community (ASCC).

The effort to build such a community for ASEAN manifests the regionalism concerning the fulfillment of the "One Southeast Asia". History and empirical evidence indicate that this idea of regionalism has been launched and endorsed by the ruling upper class often schooled in the West (Fifield, 1984, p. 128). Under the framework of multilateralism, ASEAN has been able to create norms universally accepted by its member states to facilitate the establishment and evolution of various supporting institutions. The elite-driven, multilateral nature of ASEAN integration is further reinforced by ASEAN's organizing principles, the ASEAN Way, ${ }^{1}$ which is "manifested in upholding and wise and flexible application of ASEAN fundamental principles, including those of consensus and non-interference" (Khai, 2004). The call for the ASEAN Community is basically a political exercise by the leaders of Southeast Asia (Stubbs, 2004, p. 13), and such a political exercise suggests significant changes in the institutional arrangements and mechanisms of ASEAN.

To further consolidate these arrangements, ASEAN leaders in the tenth summit in November 2004 agreed on the Vientiane Action Program aiming to outline comprehensive goals and strategies toward the realization of the ASEAN Community. As a result of long-time effort for trade and investment liberalization in the region of Southeast Asia since the early 1990s, the AEC generally centers on such 11 priority sectors as the ASEAN Investment Area (AIA), finance cooperation, and food/agriculture/forestry sectors for further integration. In addition, ASEAN leaders designed the ASC Plan of Action and the ASCC Plan of Action reflecting ASEAN's security and social

\footnotetext{
${ }^{1}$ Generally speaking, the ASEAN Way means consultation, the pursuit of consensus, the commitment to solidarity and mutual respect, the peaceful settlement of disputes, informality and minimal institutionalization, and the principle of non-intervention in domestic affairs. For details, see the work of Huang, 2000, pp. 40-44.
} 
agendas, respectively. The former touches upon commonly shared norms of behavior, conflict prevention and resolution, as well as post-conflict peacebuilding. The latter puts emphasis on building a community of caring societies, managing the social impact of economic integration, enhancing environmental sustainability, as well as promoting an ASEAN identity.

The Declaration on the Establishment of the ASEAN Charter, signed in December 2005, is indicative of the resolve of ASEAN leaders in further integrating Southeast Asia. In December 2006, ASEAN Leaders mandated the Eminent Persons Group (EPG) on the Charter of ASEAN to consider daring and creative ideas to facilitate ASEAN's integration (The ASEAN Secretariat, 2006, pp. 22-23). Taking into consideration the EPG's recommendations, ASEAN leaders signed the Cebu Declaration on the Blueprint of the ASEAN Charter in the ASEAN Summit in Cebu, the Philippines, in January 2007. In the meantime, they affirmed their strong commitment to the acceleration of the establishment of an ASEAN Community by 2015 as envisioned in the ASEAN Vision 2020 and the ASEAN Concord II. Then, in November 2007, ASEAN leaders convened in Singapore and signed the Charter of ASEAN.

The Charter of ASEAN is a positive sign of the future integration of ASEAN member states as "One ASEAN". For example, the Charter signifies a legal personality of ASEAN, and the ASEAN Political and Security Community (APSC, originally ASC) Council, the AEC Council, the ASCC Council, and the ASEAN Coordinating Council (ACC) are established to assist ASEAN leaders in putting the Charter into action, with the assistance of ASEAN Secretary General monitoring the progress of implementation and interpreting the Charter if requested (The ASEAN Secretariat, 2007).

Critics such as Thitinan Pongsudhirak argue that the Charter itself "is very diluted, to a point where it doesn't make any new ground" (Arnold, 2007). In a sense it is correct in contending that the ASEAN Charter does not lead Southeast Asia to a new ground because the principles to which ASEAN member states adhere in the ASEAN Charter - e.g., peaceful settlement of disputes, non-intervention, respect for sovereignty, equality, and territorial integrity - are the same as those in the 1967 ASEAN Declaration, the 1976 Bali Concord I, and the 1976 Treaty of Amity and Cooperation in Southeast Asia (TAC). Nonetheless, the legally binding Charter provides specific measures of intraregional dispute settlement and identifies democracy, the rule of law and good governance, and the respect 
for and protection of human rights and fundamental freedoms as shared values among the member states, which can be viewed as a breakthrough in ASEAN history. It is not far-fetched to argue that at least ASEAN has made rhetoric and limited progress toward the development of a regional intergovernmental community in Southeast Asia. Moreover, despite some criticisms (Arnold, 2007), a new human rights body of ASEAN would soon be established to safeguard human rights in the region.

The focal point of this paper is to examine the humanitarian component in the ASEAN Community. In the Preamble of the ASEAN Charter, ASEAN leaders have agreed implicitly on the necessity of a humanitarian element within the ASEAN Community - for instance, they have endorsed "the principles of democracy, the rule of law and good governance, respect for and protection of human rights and fundamental freedoms", endeavored to "ensure sustainable development for the benefit of present and future generations and to place the well-being, livelihood and welfare of the peoples at the centre of the ASEAN community building process", as well as upheld "the need to strengthen existing bonds of regional solidarity to realize an ASEAN Community that is politically cohesive, economically integrated and socially responsible in order to effectively respond to current and future challenges and opportunities". In Article 1 of the ASEAN Charter, one of the purposes of establishing such a community is to "alleviate poverty and narrow the development gap within ASEAN through mutual assistance and cooperation". Article 14 of the ASEAN Charter specifies the establishment of a new human rights body of ASEAN that would "operate in accordance with the terms of reference to be determined by the ASEAN Foreign Ministers Meeting". These are indicative of a slow and gradual emphasis of ASEAN on the humanitarian aspect.

Yet, these are insufficient to figure out the degree of the humanitarian development of the ASEAN Community. The following two sections are going to examine some of ASEAN Community's important documents to further highlight the incremental evolution of ASEAN with regard to humanitarianism.

\section{The APSC and Its Humanitarian Component}

Broadly defined, the APSC has something to do with the humanitarian development of ASEAN institutional arrangements. The goals of bringing 
Southeast Asian people a safer environment and achieving post-conflict peacebuilding best represent the growing concern of ASEAN leaders in humanitarianism.

\subsection{The Bali Concord II (October 2003)}

With the recognition of state sovereignty and the non-intervention principle, the APSC would "contribute to further promoting peace and security in the wider Asia Pacific region and reflect ASEAN's determination to move forward at a pace comfortable to all", as stated in the Bali Concord II. Moreover, in the same document, the APSC would "fully utilize the existing institutions and mechanisms within ASEAN with a view to strengthening national and regional capacities to counter terrorism, drug trafficking, trafficking in persons and other transnational crimes". Such measures as norms-setting, conflict prevention, and approaches to conflict resolution and post-conflict peacebuilding would be employed by the ASEAN member states to pursue regional and international peace and stability.

\subsection{The ASEAN Security Community Plan of Action (November 2004)}

ASEAN leaders have reiterated that the realization of the ASC "would ensure that countries in the region live at peace with one another and with the world at large in a just, democratic and harmonious environment". To achieve peacebuilding in conflict-torn areas, ASEAN member states "should assist each other in post-conflict peace building efforts, such as humanitarian relief assistance, reconstruction and rehabilitation". Recommendations made by ASEAN leaders in the Annex for the ASEAN Security Community Plan of Action include the following;

(A) Strengthening ASEAN humanitarian assistance by:

(A.1) providing safe havens in conflict areas;

(A.2) ensuring the delivery of basic services or assistance to victims of conflict;

(A.3) orderly repatriation of refugees/displaced persons and resettlement of internally displaced persons;

(A.4) ensuring safety of humanitarian relief assistance workers;

(A.5) promoting the role of humanitarian relief assistance organizations; 
(A.6) considering the establishment of an ASEAN Humanitarian Assistance Center; and

(A.7) intensifying cooperation with the United Nations and other organizations/donor countries.

(B) Developing cooperation in post-conflict reconstruction and rehabilitation in affected areas by:

(B.1) undertaking human resources development and capacity building; and

(B.2) Assisting in institutional building and promoting popular participation.

(C) Establishing a mechanism to mobilize necessary resources to facilitate post-conflict peacebuilding (e.g., a Stability Fund), including through cooperation with donor countries and international institutions.

It is evident that more specific measures have been suggested by the founding members of the APSC in dual dimensions - humanitarian disaster relief and peacebuilding.

\section{The AEC and ASCC and Their Humanitarian Components}

\subsection{The Bali Concord II (October 2003)}

The scheme of the ASCC stated in this document touches specifically upon the humanitarian element of ASEAN, whereas that of the AEC does not. For the achievement of the ASCC, ASEAN member states benefiting from economic integration have acceded to "cooperation in social development aimed at raising the standard of living of disadvantaged groups and the rural population". They have also decided that ASEAN would "further intensify cooperation in the area of public health, including in the prevention and control of infectious diseases, such as HIV/AIDS and SARS, and support joint regional actions to increase access to affordable medicines", as well as "intensify cooperation in addressing problems associated with population growth, unemployment, environmental degradation and transboundary pollution as well as disaster management in the region to enable individual members to fully realize their development potentials".

It needs to be noted here that the construction of an AEC still has to do with humanitarianism - with few written articles though, because the 
regional economic integration and individual member state's economic growth would more or less contribute to the upgrading of people's welfare in the region of ASEAN.

\subsection{The ASEAN Socio-Cultural Community Plan of Action (November 2004)}

One of the key features associated with the humanitarian component is that in the ASCC norms of social and distributive justice are upheld by addressing issues of poverty and equity, with particular care "given to vulnerable groups - children, youth, women, the elderly, and persons with disabilities - who could be the subject of abuse, neglect and discrimination". In other words, the ASCC is "a community of caring societies to address issues of poverty, equity and human development". Such a community of caring societies is aimed at the following issues:

(a) Accelerating the goal of poverty reduction within the framework of the Millennium Development Goals (MDGs). ${ }^{2}$

(b) Facilitating universal access to education for increased employability, good citizenship, and as a means of empowerment and life-long learning.

(c) Promoting the welfare of children by safeguarding their rights, ensuring their survival and full development, and protecting them from abuse, neglect, and violence.

(d) Promoting improved standards and access to education through networking and institutional collaboration, using existing regional bodies.

(e) Enabling youth to have a better future by developing their leadership skills, entrepreneurship, and technical and vocational abilities.

(f) Promoting equitable participation of women in the development process by eliminating all forms of discrimination against them.

(g) Ensuring that the elderly are adequately cared for by promoting community-based support systems to supplement the role of the family as primary caregiver.

\footnotetext{
${ }^{2}$ In Appendix A of the ASEAN Socio-Cultural Community Plan of Action, there are 21 measures proposed by the ASEAN leaders, most of which are similar to those proposed in the ASCC Plan of Action.
} 
(h) Augmenting and supporting the efforts of sectoral bodies to prevent and combat human trafficking, particularly in women and children, through comprehensive policies and measures.

(i) Strengthening the system of social welfare through the enhancement of national capacities in responding to emerging social issues.

(j) Promoting health and nutrition, including through advocacy on health-related issues and healthy lifestyles.

Activities of the ASCC have fallen into three categories: nationally-driven initiatives; regional activities that enhance or complement national initiatives through the establishment of regional networks and joint regional approaches (e.g., the development of regional work programs); and regional activities that involve setting up of regional mechanisms or standards.

\subsection{Chairman's statement of the 13th ASEAN summit (November 2007)}

ASEAN leaders have again echoed the suggestions made by the civil societies and resolved to "deepen economic integration and communitybuilding efforts, pay attention to well-being and livelihood of vulnerable groups in society, and promote democracy, good governance and human rights". More importantly, the "Saffron Revolution" in Myanmar that took place in the second half of 2007 has somewhat strengthened ASEAN's determination to be engaged more assertively in the internal affairs of Myanmar in order to meet humanitarian needs and standards widely accepted by the international community. It is the very first time for ASEAN to send out a loud and clear message with a humanitarian implication to the military junta in Myanmar that "the Myanmar Government should continue to work with the UN in order to open up a meaningful dialogue with Daw Aung San Suu Kyi and the National League for Democracy (NLD); make full use of the good offices of the UN SecretaryGeneral and Professor Gambari in this process; lift restrictions on Daw Aung San Suu Kyi and release all political detainees; work towards a peaceful transition to democracy; and address the economic difficulties faced by the people of Myanmar".

To conclude, the APSC and ASCC have been the leading official documents of ASEAN to plan and implement humanitarian measures, while the AEC has served as a crucial championing force for ASEAN to fulfill the goal of building a people's community based on humanitarianism. 


\section{Humanitarianism in the ASEAN Community: An Emerging Trend}

The previous section has referred to the increased awareness of humanitarianism within ASEAN. In fact, outside the region of Southeast Asia, ASEAN member states have joined the mainstream international society to facilitate the growth of the humanitarian concern, depending on the specific cases. Can one thus argue that ASEAN has had an evidently emerging humanitarian component in its words and deeds? To answer this question, this section will first further examine what ASEAN has done outside the region of Southeast Asia, and then look at how ASEAN has done as critical cases took place in Southeast Asia.

\subsection{More proposals and greater consensus}

At the global level, concerns of ASEAN leaders for humanitarian assistance and relief can be briefly examined by their attitude toward global human rights treaties. All member states of the United Nations, including all ASEAN member states, have signed the 1948 University Declaration of Human Rights (UDHR). Of the seven major human rights conventions, only the 1981 Convention on the Elimination of All Forms of Discrimination against Women, the 1989 Convention on the Rights of the Child, and the 2008 Convention on the Rights of Persons with Disabilities were ratified by all ASEAN governments. Appendix shows that only half of the ASEAN governments Cambodia, Indonesia, Laos, the Philippines, and Thailand - have ratified all conventionally defined major human rights conventions. The 1987 Convention against Torture and Other Cruel, Inhuman or Degrading Treatment or Punishment is the "least popular" multilateral human rights treaty among ASEAN governments - only five have ratified it. Yet, with the increased numbers of signatories and ratifications, it is possible that ASEAN leaders' awareness for humanitarian concern or willingness to work on human rights-related issues has been gradually arisen.

The varying degree of ASEAN member governments' definition and recognition of human rights results largely from ASEAN's reservations about accepting intervention to advocate the notion of universal human rights standards, as well as from the so-called "Asian values" that tend to distinguish ASEAN's soft-authoritarian rule from Western democracies. The principle of non-intervention that has been upheld highly by ASEAN 
cannot be challenged by any urgent request out of humanitarian reasons; in addition, the "Asian values"-related philosophical and political thinking behind ASEAN has helped justify an alternative human rights environment in which rapid economic growth brings stronger forceful measures against political dissidents and military resistances domestically (Mohamad, 2002, pp. 232-236).

ASEAN leaders in region-wide official documents also have shown their increased concern for humanitarian relief and assistance. For instance, in the Kuala Lumpur Declaration on the East Asia Summit, in December 2005, "narrowing the development gap in East Asia, through technology transfer and infrastructure development, capacity building, good governance and humanitarian assistance" has become a common goal shared by leaders of ASEAN, Australia, the People's Republic of China, Japan, Republic of Korea, and New Zealand. On the same occasion, the East Asia Summit brought up the Declaration on Avian Influenza Prevention, Control and Response, undertaking a series of measures preventing the avian influenza outbreak in the region that would not only influence human health but also impact many industries on which human welfare had relied. They have decided to adopt a "multi-sectoral/multi-disciplinary approach at the national and regional level" to coordinate cooperation among participating member states and relevant international organizations such as the World Health Organization and the World Bank, as well as enhance capacity building in coping with the avian influenza and other pandemics.

The Chairman's Statement of the Second East Asia Summit in January 2007, for example, also has a timely humanitarian component. In light of natural disasters causing tremendous loss of life and damage to property in the region in recent years, the ASEAN leaders have found imperative strengthening cooperation and coordination among national emergency response and management mechanisms in order to better natural disaster response preparedness and mitigation.

ASEAN leaders' emphasis on humanitarian relief and assistance may be better presented by ASEAN's newly created institutions which are divided into two categories: disaster assistance and relief as well as rural development and poverty eradication.

Concerning the disaster assistance and relief, ASEAN's effort to cope with natural disasters was first seen in the ASEAN Declaration on Mutual 
Assistance on Natural Disasters, signed in Manila, June 1976. However, not until the year of 2003 has ASEAN taken this task seriously.

The ASEAN Committee on Disaster Management (ACDM) established in early 2003 consists of heads of national agencies/organizations responsible for disaster management of ASEAN member states. To respond effectively to assist member states during major disasters and calamities, ASEAN Ministerial Meeting on Disaster Management (AMMDM) was first held in 2004, followed by the ASEAN Agreement on Disaster Management and Emergency Response (AADMER) in July 2005 in Vientiane, Laos. The AMMDM and the ASEAN Standing Committee are two major institutions providing policy guidance to the ACDM. The AADMER provides for the establishment of the ASEAN Standby Arrangements for Disaster Relief and Emergency Response (Article 9), with the hope that member states will be able to identify and mobilize on a voluntary basis the available assets and capacities for emergency and disaster management.

In October 2011, ASEAN officially established the ASEAN Coordinating Center for Humanitarian Assistance on Disaster Management (AHA Center) as the coordination body of AADMER. Under the Standard Operating Procedure for Regional Standby Agreements (SASOP), the major function of the AHA Center at the very beginning was simply to collect and analyze information on the affected countries and the required assistance, including requests and offers, and on the assistance promised or provided by the donating countries. Nowadays, in addition to the above-mentioned functions, the AHA Center has been tasked to deal with the mobilization of assets and capacities, as well as the demobilization of assistance and reporting. Moreover, the AHA Center has established emergence response and assessment teams to work with other parties (Tumonong, 2016).

With regard to the effort of rural development and poverty eradication, despite the acknowledgement of ASEAN that poverty and human needs were most deeply felt in the rural areas, it is in fact not easy to discern the real effort made by ASEAN to promote rural development and eradicate poverty in the first 30 years of ASEAN history.

In practice, ASEAN convened meetings of the ASEAN Ministers on Rural Development and Poverty Eradication (AMRDPE), with the assistance of the Senior Officials Meeting on Rural Development and Poverty Eradication (SOMRDPE). The first informal AMRDPE meeting was held in Jakarta, December 1998, looking for a comprehensive approach to the 
elimination of poverty, the enhancement of rural development, and the reduction in social impact of poverty and development in the region of Southeast Asia. The ASEAN Framework Action Plan on Rural Development and Poverty Eradication was then launched in 2004, in cooperation with the ASCC in the Bali Concord II and the ASEAN Vision 2020 to alleviate poverty and socio-economic disparities. The measures such as narrowing the digital divide, strengthening social protection, enhancing investment in human resource development, and stressing shared partnerships and responsibilities are prerequisites for the achievement of the development goals with an emphasis on equality. In January 2007, the fifth AMRDPE has decided to accelerate the implementation of three areas under the Framework Action Plan: narrowing the digital divide; employment and income generation i.e., enhancing investment in human resource development; and partnership, decentralization, and local participation - i.e., shared partnerships and responsibilities.

All these under AMRDPE are part of the obligations of the ASEAN Ministerial Meeting on Social Welfare and Development (AMMSWD), too. The sixth AMMSWD in 2007 in Hanoi, for example, has been "committed to promoting cooperation towards an inclusive, barrier-free and rightsbased society with protection of well-being of people against any risks; and creating equal opportunities for every member of the society to social services, especially for persons with disabilities, older persons, children in special circumstances, victims of trafficking and disasters". In the meantime, ASEAN plus Three correspondingly held its first Ministerial Meeting on Social Welfare and Development in Hanoi. In December 2007, too, there was a second ASEAN plus Three Ministerial Meeting on Social Welfare and Development in Hanoi, with the recognition of the ASEAN Strategic Framework and Plan of Action for Social Welfare, Family and Children (2007-2010). The third said meeting was held in Brunei Darussalam in 2010, after the Strategic Framework and Plan of Action has been carried out, and developed a five-year plan to promote the goals in collaboration with the United Nations and other related agencies and organizations.

The ASEAN Intergovernmental Commission on Human Rights (AICHR) was created in October 2009, as a constructive response to the Joint Communique of the ASEAN Foreign Ministers (AMM) in July 1993 and to the ASEAN Charter (mainly Article 14) which states the need to establish a human rights body within ASEAN. In addition to the annual and five-year 
work plans, the AICHR has carried out various projects and researched and trained pertinent issues on human rights in ASEAN.

The ASEAN Commission on the Promotion and Protection of the Rights of Women and Children (ACWC) was inaugurated in April 2010, in Hanoi. It is in coordination with AICHR, and it reports to AMMSWD and the ASEAN Committee on Women.

It goes without saying that ASEAN's scheme of social welfare and development, including rural development and poverty eradication, has been associated highly with the fulfillment of the ASCC and has come into shape in the mid-2000s. Specifically, ASEAN leaders understand that the promotion of the ASCC "will require intensive and sustained capacity building at the national and regional levels in a wide range of areas..." and that resource mobilization "will remain to be a key challenge for implementing various activities..." (The Association of Southeast Asian Nations, 2004). The same capacity building and resource mobilization are of great importance for the maintenance and enhancement in the humanitarian feature of ASEAN.

\subsection{More rhetoric, less proactive?}

ASEAN leaders considered a salient humanitarian component in the process of establishing the ASEAN Community. In recent years, ASEAN leaders' considerations have come to realize with more politically or legally binding documents paving the way for better humanitarian assistance and relief in Southeast Asia. Regardless of their real motive, the stress for humanitarian concern has been often seen in ASEAN meetings. When these documents and ensuing measures, operations, and institutional designs are to be realized, it is obvious that ASEAN is in lack of the capacity to act that can facilitate in a broader way the development of humanitarian assistance and relief in the region. Most of its effort seems to focus on disaster prevention and relief, which is a feature that has been certainly needed by most of the ASEAN member states and been easier for ASEAN leaders to construct as a proof of progress.

Three earlier cases will be briefly examined here to demonstrate the ineffectiveness of ASEAN in regional humanitarian tasks. The first case is the earthquake and tsunami hitting Southeast Asia on December 26, 2004. The second case is concerned with the proposal as to the creation of a regional humanitarian relief coordinating center in Southeast Asia. The last one has to do with Myanmar. 


\subsubsection{The December 26, 2004, earthquake and tsunami}

The December 26, 2004, earthquake and tsunami affected greatly some South and Southeast Asian countries, including Indonesia and Thailand. In hard-hit Aceh only, reportedly the deaths reached about 170,000. Although politics were set aside to alleviate suffering in the shortest time, ASEAN, still discussing the idea of an ASEAN Community, was not empowered with sufficient capacity for such an emergency relief. As a result, in most cases it was the international charity groups and foreign governments, with the aid of regional military forces, including the US Navy, which rushed in with food and medical care (Bayron, 2005).

To manage future natural disasters and humanitarian emergencies, the special ASEAN leaders' meeting was held in Jakarta on January 6, 2005. At that meeting ASEAN leaders adopted the Declaration on Action to Strengthen Emergency Relief, Rehabilitation, Reconstruction and Prevention on the Aftermath of Earthquake and Tsunami Disaster on 26 December 2004, in the hope that a three-phase measure - emergency relief, rehabilitation and reconstruction, and prevention and mitigation - aided by the international community in affected areas could be carried out effectively. Moreover, the ASEAN Disaster Information Sharing and Communication Network, established in accordance with the ASCC Plan of Action, became one of the top priorities for the 2004-2010 ASEAN Regional Program on Disaster Management (ARPDM) under the ACDM, and the AHA Center was created in October 2011. It appears fair to argue that a slow but working institutional and capacity building was therefore underway.

\subsubsection{The creation of a regional humanitarian relief coordinating center}

In 2006, Malaysian Defense Minister Najib Tun Razak at the annual Shangri-La Dialogue meeting proposed the launch of a regional humanitarian relief coordinating center (The Kyodo News, 2006). Two years after Najib's proposal for a regional humanitarian relief coordinating center, an interim AHA Center was established in Jakarta in June 2008, as an auxiliary mechanism for the implementation of the ASEAN Agreement to Disaster Management and Emergency Response. The slow start may indicate that, in the field of disaster management and relief, a great deal of work "has been done to develop much better coordination mechanisms" among the United Nations, private groups, and donors in Southeast Asia (Blume, 2008). Yet, that also shows that ASEAN with numerous recommendations and 
measures regarding humanitarian disaster management was still learning how to rely on the mobilization of the international community and the coordination among international and local private sectors and organizations to deal with these natural disasters.

\subsubsection{The Myanmar issue}

Myanmar has to do with ASEAN's humanitarian aid and relief in the following three aspects - natural disasters that resulted in enormous deaths, injuries, and forced relocation of people; as well as the totalitarian control of the junta that led to the loss of social justice and a salient disparity in political and economic rights. ${ }^{3}$

On May 2, 2008, for instance, Cyclone Nargis made a landfall in Myanmar and caused at least some 130,000 fatalities and economic damage estimated at more than US $\$ 10$ billion. Over 2,000,000 people in Southern Myanmar needed immediate aid.

In spite of the fact that ASEAN sent an assessment team to Rangoon to determine how best to help the survivors in desperate need of food, shelter, and medicine, Myanmar's junta government denied any regional and international assistance at the very beginning of the catastrophic disaster. Singaporean Prime Minister Lee Hsien Loong argued that the Myanmar Government's response and decision were regrettable, because the rest of ASEAN member states had been "deeply concerned by the massive suffering of the victims, which a more rapid international relief operation could have minimized" (Agence France Presse, 2008). Later, the junta allowed the international community to carry out relief work in the area of the Irrawaddy Delta probably because the scope of the disaster was too huge to handle single-handedly.

As former ASEAN Secretary-General Surin Pitsuwan pointed out, getting aid and relief work to Myanmar is a long-term process. The ASEAN Foreign Ministers Meeting in Singapore in July 2008 decided in what form and for how long ASEAN would remain engaged in the case of Myanmar. In addition, Surin also called for "more coordination and more support for the NGOs and the international organizations to even expand their

\footnotetext{
${ }^{3}$ Due to the page limit, this paper does not discuss the more recent issue of the Rohingya people and the violence associated with them, and their unprotected communities in Myanmar.
} 
activities" (Jha, 2008). In general, ASEAN did moderately to help Myanmar get through the most difficult phase, both due to the resistance from Myanmar's junta and due to the lack of substantial measures and coordination among ASEAN member states.

The rule of the junta in Myanmar, along with ASEAN's principle of nonintervention, is another issue challenging ASEAN's coordinated humanitarian policy. It was commonly seen that ASEAN leaders tended to remain ignorant of what was going on inside Myanmar. They also kept distant from serious human rights violations or humanitarian needs in Myanmar. For example, in the Chairperson's Statement of the Twelfth ASEAN Summit in Cebu, the Philippines, in January 2007, ASEAN leaders avoided commenting on the human rights violations and humanitarian needs of Myanmar; instead, they simply encouraged Myanmar to make greater progress toward national reconciliation by releasing the political dissidents placed behind prison bar and engaging in effective dialog with all parties concerned.

Had it not been the "Saffron Revolution" in the second half of 2007 and ensuing strong international pressure, ASEAN would not have adopted a relatively assertive posture to deal with the humanitarian and human rights concerns in Myanmar at the Thirteenth ASEAN Summit held in Singapore, in November 2007. At this summit, ASEAN asked the Myanmar Government to make good use of the United Nations to engage in dialog with Aung San Suu Kyi, free all political detainees, transform from the junta regime to democracy, as well as heed to economic difficulties in Myanmar society.

The Thirteenth ASEAN Summit denotes a stronger humanitarian concern of ASEAN for the domestic situation of Myanmar. However, no further concrete action of ASEAN was taken since this summit. ASEAN still counted on the United Nations to deal with humanitarian needs and human rights violations in Myanmar largely because it did not want to break away from the principle of non-intervention, a time-honored principle in ASEAN, ${ }^{4}$ not to mention that none of the aforementioned ASEAN political and legal documents devised specific rules or codes of conduct for ASEAN to get involved in the provision of humanitarian aid. Moreover, the prevention of human rights infringements in individual member states has been a primary goal of the AICHR, but what has been mostly seen are the

\footnotetext{
${ }^{4}$ This analysis is based on the author's interview with an anonymous New York City-based expert on UN peacekeeping and conflict resolution, April 3, 2008.
} 
multilateral, consensus-based consultations rather than practical and effective measures. ${ }^{5}$

\section{Concluding Remarks}

The 52-year-old ASEAN has equipped itself with an obvious humanitarian component. Historic documents of ASEAN such as the Bali Concord II and specific humanitarian assistance and relief ones are indicative of the consensus among ASEAN member governments to carry out humanitarian actions if needed and requested. Nonetheless, ASEAN's capacity building in this regard and irrelevance in humanitarian assistance and interventions resulting from domestic politics or intraregional armed conflicts have led to the fact that ASEAN will either appeal to the United Nations, charity organizations, and state and private donors for their resources used in natural disasters or rely largely on the United Nations to intervene in situations where human welfare in a specific country is being infringed by the central or local government.

The ASEAN Charter only has a very small portion of humanitarianismrelated statements and measures. However, as stated before, the ASEAN Community's three pillars have more or less contributed to the growing concern and development of the humanitarian component in ASEAN. Perhaps "selective humanitarianism" is a right term to describe the compromise of ASEAN in real-world cases of humanitarian assistance and interventions. Although the origins of ASEAN Community's humanitarianism have been influenced obviously by state sovereignty - a conventional concept that has been endorsed firmly by ASEAN member governments, slow progress has been made after a series of important cases or incidents that needed ASEAN's humanitarian involvement and have possibly helped ASEAN stay intact when ASEAN was confronted with these testing cases or incidents.

\section{Acknowledgments}

Part of this work is based on the paper "An Emerging Humanitarian Component in the ASEAN Community?" delivered at the Second Global International Studies Conference, University of Ljubljana, Slovenia, July 23-26, 2008.

\footnotetext{
${ }^{5}$ See, for instance, The Wall Street Journal, 2009; Wahyuningrum, 2014, pp. 25-26; and Chachavalpongpun, 2018.
} 
The Origins of the ASEAN Community's Humanitarian Component

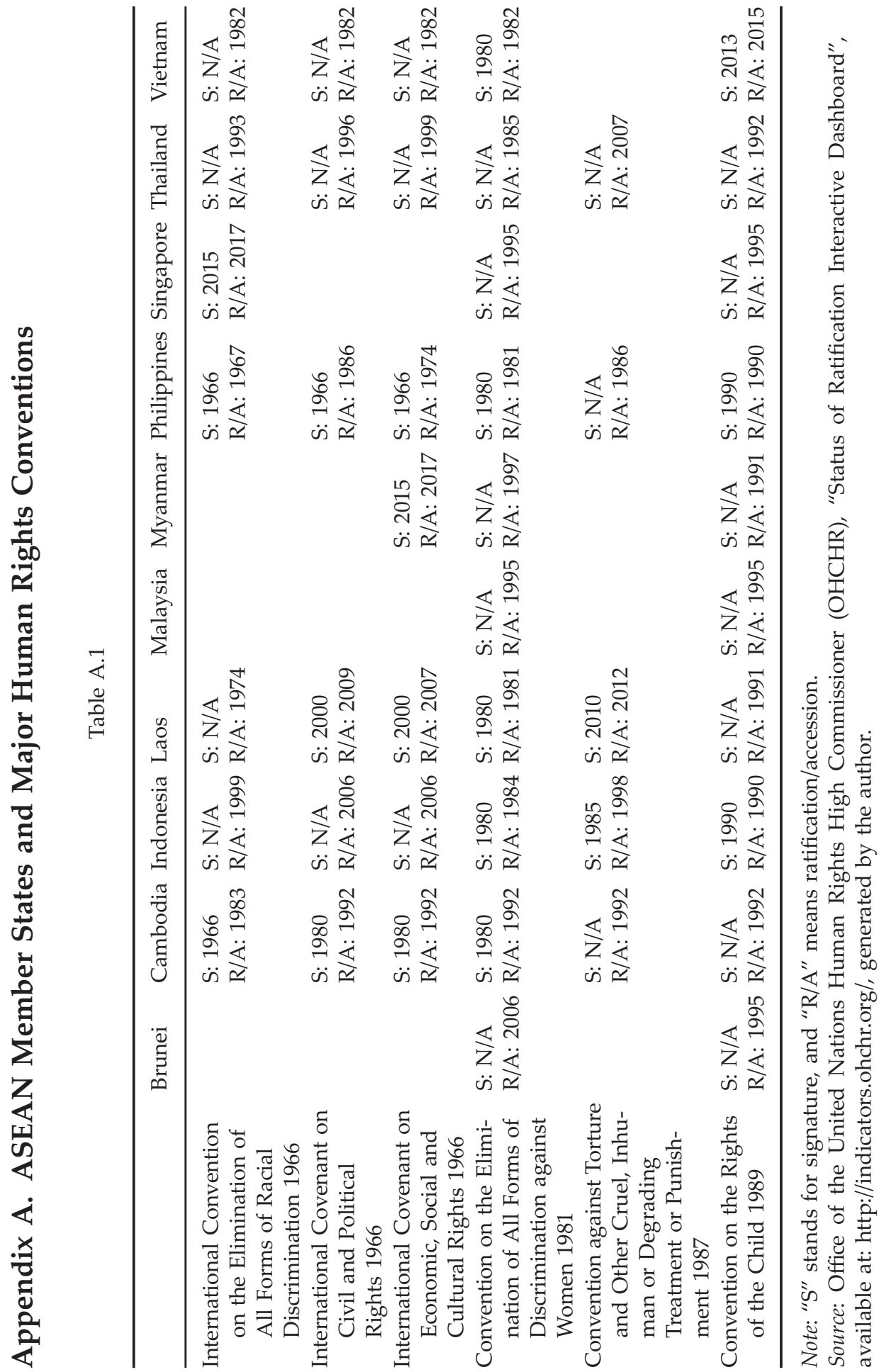




\section{References}

Agence France Presse (2008), "Burma's Delay on Aid Cost Tens of Thousands of Lives: Gates," ABC News Online, May 31, https://www.abc.net.au/news/2008-05-31/burmasdelay-on-aid-cost-tens-of-thousands-of/2454960.

Claudia Blume (2008), “4 Years after Tsunami, Asia Better Prepared for Disasters," Voice of America, May 23, https://reliefweb.int/report/maldives/4-years-after-tsunami-asia-betterprepared-disasters.

Heda Bayron (2005), "Asian Tsunami Reconstruction Moves Forward, Challenges Remain," Voice of America, June 20, https://reliefweb.int/report/sri-lanka/asian-tsunami-reconstruction-moves-forward-challenges-remain.

Kwei-Bo Huang (2000), The Association of South East Asian Nations' Confidence and Security Building with the People's Republic of China: Internal Constraints and Policy Implications, Maryland Series in Contemporary Asian Studies, Vol. 6 - 2000 (161) (Baltimore: University of Maryland School of Law).

Lalit K. Jha (2008), “Myanmar: More Relief Effort Needed: ASEAN Secretary-General,” The Irrawaddy, July 14, https://reliefweb.int/report/myanmar/myanmar-more-relief-effortneeded-asean-secretary-general.

Malyn Tumonong (2016), "Five Years of AHA Centre: Experiences, Challenges and Future Outlook of Disaster Management in ASEAN," Presentation delivered at United Nations/ India Workshop on the Use of Earth Observation Data in Disaster Management and Risk Reduction: Sharing the Asian Experience, March 8-10, Hyderabad, India, http://www. unoosa.org/documents/pdf/spider/activities/2016/india/Day3/Plenary_session2/5_Years_ of_AHA_Centre_mmltumonong.pdf.

Maznah Mohamad (2002), "Towards a Human Rights Regime in Southeast Asia: Charting the Course of State Commitment," Contemporary Southeast Asia, 24(2): 232-236.

Phan Van Khai (2004), “ASEAN Lecture by H. E. Mr. Prime Minister Phan Van Khai," Hanoi, August 8, https://asean.org/asean-lecture-by-he-mr-prime-minister-phan-van-khai.

Pavin Chachavalpongpun (2018), "Is Promoting Human Rights in ASEAN an Impossible Task?" The Diplomat, January 19, https://hediplomat.com/2018/01/is-promoting-humanrights-in-asean-an-impossible-task/.

Russell H. Fifield (1984), “'Southeast Asia' and 'ASEAN' as a Regional Concept," in R. A. Morse, ed., Southeast Asian Studies: Options for the Future (Lanham, Maryland: University Press of America), pp. 125-128 [Cited from Amitav Acharya (2000), The Quest for Identity: International Relations of Southeast Asia (Singapore: Oxford University Press), p. 99].

Richard Stubbs (2004), “The Region: ASEAN in 2003: Adversity and Response," in Daljit Singh and Chin Kin Wah, eds., Southeast Asian Affairs 2004 (Singapore: Institute of Southeast Asian Studies), pp. 3-17.

The Association of Southeast Asian Nations (2004), "The ASEAN Socio-Cultural Community (ASCC) Plan of Action," Kuala Lumpur, November 30, https://asean.org/?static post=the-asean-socio-cultural-community-ascc-plan-of-action. 
The Kyodo News (2006), "ASEAN Defense Ministers Mull Disaster Relief Cooperation," June 5.

The ASEAN Secretariat (2006), "Report of the Eminent Persons Group on the ASEAN Charter," Meeting of the Eminent Persons Group on the ASEAN Charter, Kuala Lumpur, December (Jakarta: The ASEAN Secretariat), pp. 1-55.

The ASEAN Secretariat (2007), "Interesting Changes to the ASEAN Institutional Framework," Statements and Communiques, November 20, https://asean.org/interestingchanges-to-the-asean-institutional-framework/.

The Wall Street Journal (2009), “ASEAN's Toothless Council,” Opinion Asia, July 22, https:// www.wsj.com/articles/SB10001424052970203517304574303592053848748.

Wayne Arnold (2007), "Historic ASEAN Charter Reveals Divisions," The International Herald Tribune, November 20, http://www.iht.com/articles/2007/11/20/asia/asean.php.

Yuyun Wahyuningrum (2014), “The ASEAN Intergovernmental Commission on Human Rights: Origins, Evolution and the Way Forward," Discussion Paper (Stockholm, Sweden: International Institute for Democracy and Electoral Assistance), pp. 1-36, https://www. idea.int/sites/default/files/publications/the-asean-intergovernmental-commission-onhuman-rights-origins-evolution-and-the-way-forward.pdf. 